DE DE GRUYTER

OPEN

Polish Cartographical Review

Vol. 47, 2015, no. 4, pp. 213-224

DOI: $10.1515 /$ pcr-2015-0016

BEATA KONOPSKA

Department of Cartography and Geomatics

Maria Curie-Skłodowska University, Lublin

beata.konopska@o2.pl

\title{
Adaptations of foreign geographical atlases from before 1989 published for the Polish users
}

\begin{abstract}
The adaptations of foreign cartographical works are the constant publishing practices. The subject matters of these studies are the adaptations of foreign geographical atlases, prepared for the Polish users before 1989.

This article attempts to prove the thesis, that the activities of authors and publishers measured by a number and degree of adjustment of the above mentioned adaptations to the needs of the Polish customers in the scope of Polish adaptations of foreign geographical atlases are dependent on the external circumstances, mainly, on the political and socio-economic ones. The aims of these research studies are brought to determine a scope of changes adapting the foreign atlases to the Polish users in the context of the workshop of cartographer and to compare these kinds of publishing activity in the respective periods. The results of these works confirmed the thesis, which was put at the beginning, that the activities of authors and publishers in the field of adaptation depend on the external circumstances. It is clear from the analysis of the examined adaptations, that the greatest activity in this scope is characterised by two periods: the period of partitions of Poland and the next period of activity after the year 1989.

Referring to the kinds of adaptations, which were proposed in the article written by B. Konopska and J. Pasławski (2015), it is necessary to mention, that the main principles of the compilations of adaptations in the earlier periods were just the same as we have today. All the atlases can be divided into the basic adaptations and complex ones. Using the reviews and overviews of the adaptations written at the time, when they were issued, we can also say, that the geographical names were and now are the biggest problems for the authors.
\end{abstract}

Keywords: geographical atlases, the adaptation of atlas, geographical names

\section{Introduction}

In the second issue of the Volume no 47 of "The Polish Cartographical Review" for the year 2015 were presented the results of the study, the aim of which was to determine a degree of adjustment of foreign publications to the needs of Polish customers in the context of the workshop of cartographer. The study, mentioned above, involved the Polish adaptations of foreign geographical atlases, which appeared after the year 1989. Two types of adaptations were determined: the basic one, the authors of which limited themselves only to the translations of the original publications into Polish, without interfering into the structure of each work and correcting the factual errors, as well as the complex one, the authors of which translated not only the text layer, but additionally they introduced a newly compiled part concerning Poland, replacing the ordinary pages dedicated to the presentation of a country, from which an original work came, by the mentioned part of Poland. Moreover, the conducted study allowed to determine the main editorial tasks related to the issuance of adaptations and indicated the translation of geographical names as the most serious workshop problem, which was not always solved effectively by the creators of adaptations. (B. Konopska, J. Pasławski 2015).

The research material came from over twenty years of the period, in which the activity of Polish publishers in the scope of adaptations of 
foreign publications was the biggest, counting from the end of the Second World War. The origin of that extraordinary recovery of publishing activity was explained by the changes, that had taken place in the external environment, with an indication of socioeconomic transformation after 1989 as the main growth factor. The result of the connection of publishing decisions together with the volatility of external conditions provokes outright for the further research on the phenomenon of adaptation, as well as the assessment of its character in relation to the other periods in the history of Poland, especially in the relation to the complicated political fate, under the influence of which the changes in the mentality of Polish society had been carried out. In the light of the foregoing, one can formulate a thesis, that the activity of authors and publishers measured by a number and degree of adjustment of Polish adaptations of foreign geographical atlases to the needs of Polish customers is dependent on the external circumstances, mainly, on the political and socioeconomic ones.

According to the staked thesis, the research goal was brought to determine a scope of changes adapting the foreign atlases to the Polish users in the context of the workshop of cartographer and to compare these kinds of publishing activities in the respective periods. The answers to these questions should, in conjunction with the results described in the above mentioned article, make it easier to trace the process of adjusting the foreign publications to the Polish audience and to confirm the proposed division into the kinds of adaptation.

The objects of the studies were the Polish adaptations of foreign geographical atlases, which were published before the year 1989. In accordance with the accepted thesis and research methodology applied to the publications issued after the year 1989, the collected material was ordered in a line with the historical periods adopted in the Polish historiography. The oldest adaptation, which was looked closely at, came before the fall of the Polish-Lithuanian Commonwealth (until 1795). The next adaptations, which were taken into account, were issued at the time of the partitions (1795-1918), the further ones came from the time of the Second Republic of Poland (1918-1939), and the last ones, which were brought under the conside- rations, had been issued since the end of the Second World War until the year 1989.

Reviewing the literature on the subject, it was noted, that the issue of adaptations of foreign geographical atlases was taken mainly in the form of articles, the authors of which payed attention to different aspects of the workshop of cartographer. The invaluable assessment resources of adaptations, not only relative to the workshop, but also from the point of view of their social functions, were the reviews appearing almost on a regular basis. In the most cases, their language and a focus of statements reflect the social atmosphere in the country and the position of Poland on the international arena.

One of the most valuable studies is the article written by J. Piasecka (1991), published on the pages of "The Polish Cartographical Review", about the Polish translations of school geographical atlases. The works by B. Olszewicz (1998, 2003), which are the guided cartographical publications, are also very useful. Some supplement to this issue brings the review article written by W. Spallek (2014), which was included into the Volume 18 of the series "From the History of Cartography". The unpublished master thesis, made under the guidance of Professor Władysław Pawlak at the Department of Cartography at the University of Wroclaw, in which Wielki Atlas Geograficzny (The Great Geographical Atlas) (1895-1906) called the Atlas of Wacław Nałkowski and Andrzej Świętochowski is also very noteworthy (B. Kosiorowska 1997).

\section{The analysis of the sources}

\subsection{Until the fall of the Polish-Lithuanian Commonwealth}

The first well-known adaptation of foreign geographical atlases for the Polish readers had been prepared by a priest of the Order of Piarists Dominik Szybiński (1730-1799), who had translated from French Atlas dziecinny, czyli nowy sposób do nauczania dzieci geografii, krótki, łatwy.... (The children's atlas, that is a new way in teaching the geography for children: short, easy...). The atlas was released by Michael Groell His Majesty Bibliopol and Court Commissioner in Warsaw, in 1772. In 
the same year, so in the year of the first partition of Poland, the atlas had one more edition (L. Szaniawskia 1987). The subsequent edition was in 1778, the next one, probably, in 1782 (B. Olszewicz 2003). The Atlas... contains 22 maps, which are so original, that the geographical objects do not have the names, but only the markers in the letters and numbers. The content of the tasks contained in the publication refers to these markers. In the preface to this atlas the author highlighted the efficacy of such a type of maps in teaching (D. Szybiński 1772 , p. 3 unnumbered). The form of Atlas... is quite close to the form of handbook. The analysed adaptation matched the current publishing activity of that time, because in the days of the National Commission of Education (KEN) there were for about 50 textbooks for geography issued, and throughout the eighteenth century
- more than 100, including about 15, which were the translations (K. Augustowska 1960).

The adaptation compiled by D. Szybiński is a complex adaptation, which is considerably different from the original. The atlas was expanded in the part concerning the Polish Kingdom (fig. 1) and the Grand Duchy of Lithuania (J. Piasecka 1991), that together with the tasks constitutes $1 / 3$ of the volume. In addition to the maps, the Atlas includes two tables (no. 23 and 24), illustrating the content of the chapter "The science of the sphere". At the end of the atlas there is an index of nearly 1,450 geographical names with the references to the pages of the text. The vast majority of the names has the only one reference.

This atlas did not have an unambiguous assessment (J. Lewicki 1910, M. Polaczkówna 1925). Released a year before the appointment

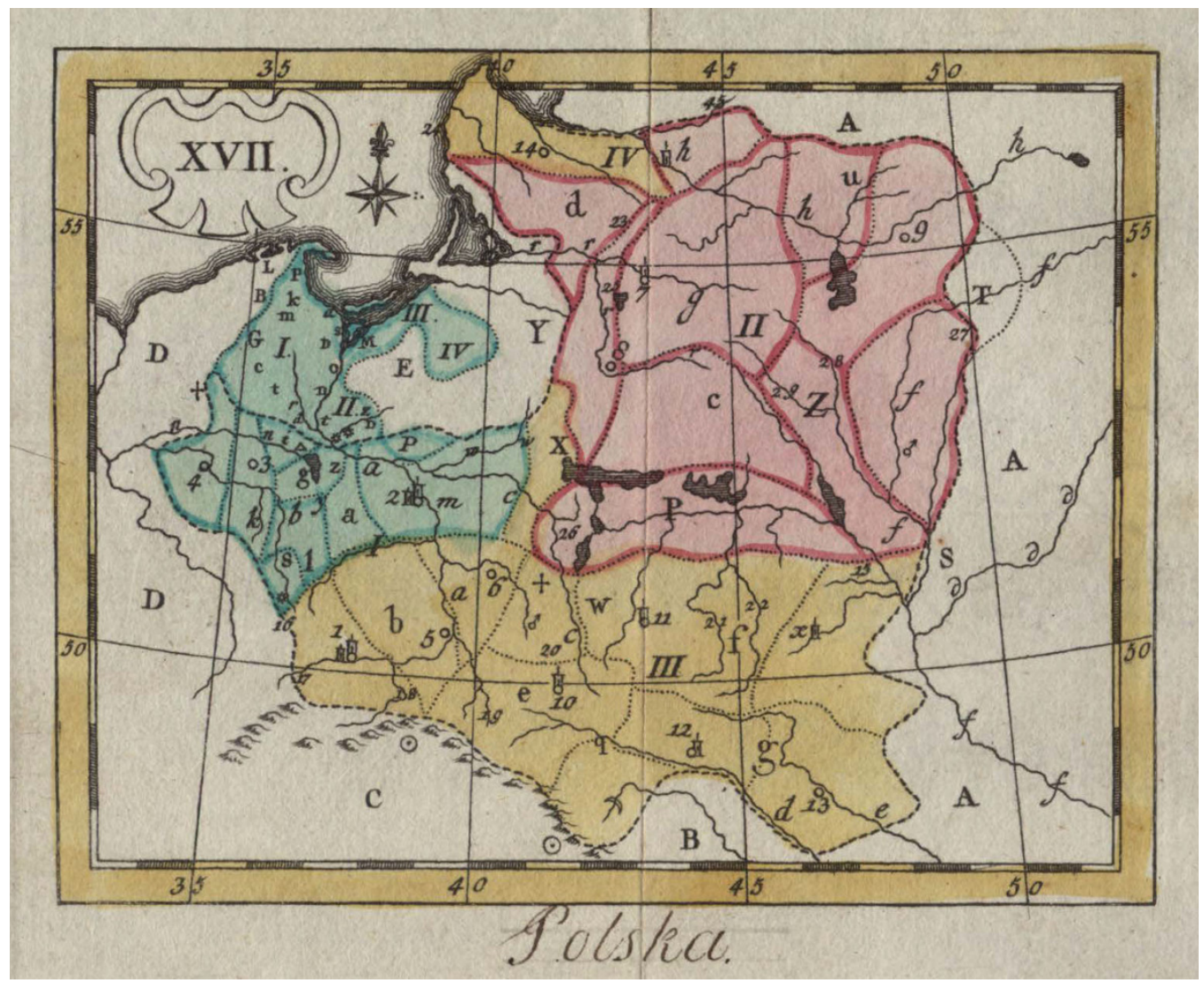

Fig. 1. The map of the Polish Kingdom from the atlas compiled by D. Szybiński (source: Plock Digital Library) 


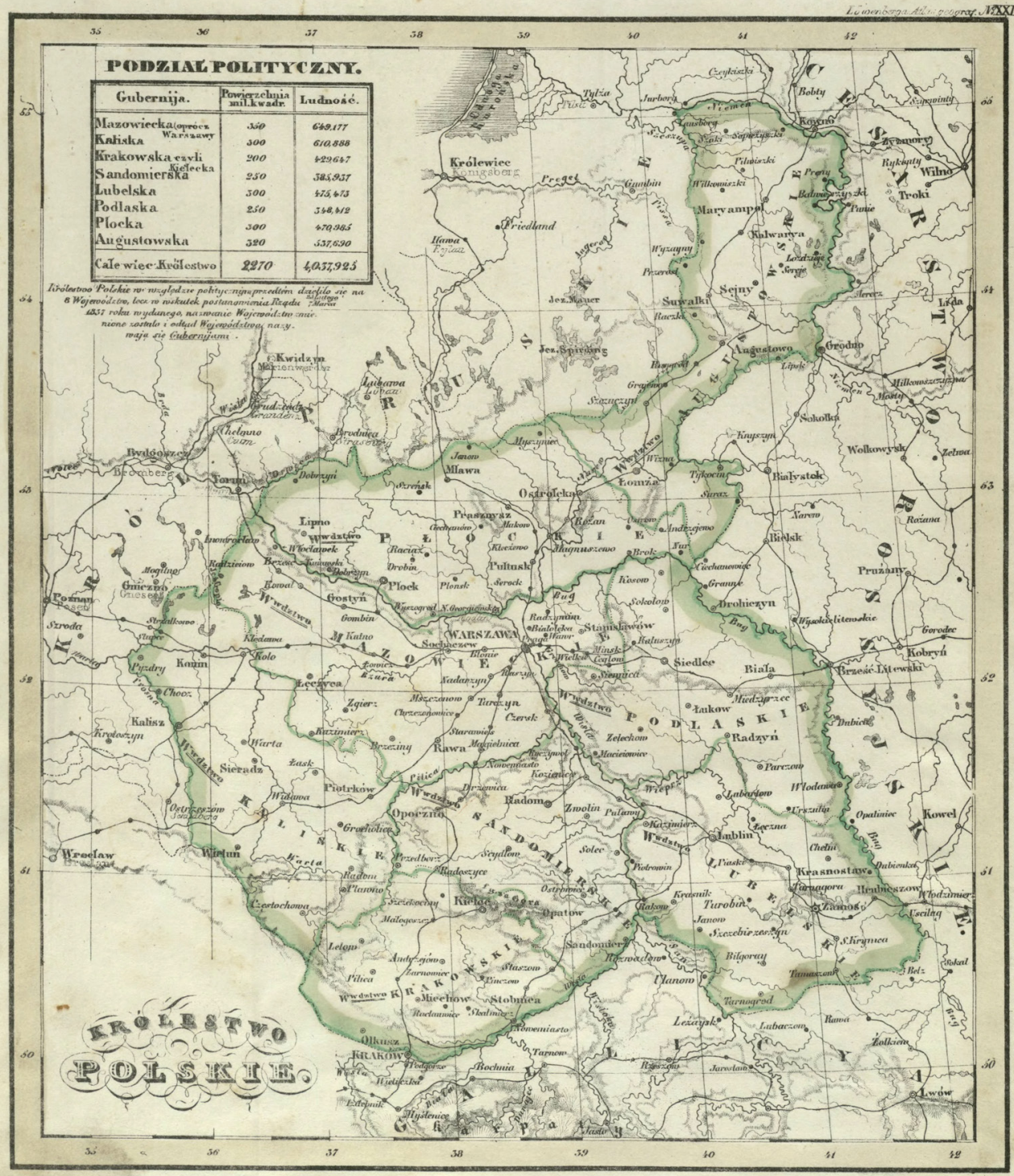

Fig. 2. The map of the Polish Kingdom from Atlas geograficzny dla użytku szkolnego i prywatnego... (The geographical atlas for school and personal use) by J. Loewenberg (source: KUL Digital Library)

of KEN, it did not tie in with its Act (M. Łodyński 1960). However, it was recommended in 1777 by Tadeusz Krajewski in his publication Gry nauk dla dzieci służące do ułatwienia ich edukacji... (Science games for kids used to facilitate their education...) and in 1790 by Maksymilian Prokopowicz in Sposób nowego najłatwiejszego pisania i czytania razem dla panienek... (The new way of easiest reading and writing together for the girls...) (M.E. Kowalczyk 2014). 


\subsection{The times of partitions}

After the year 1800 Mały atlas kieszonkowy z siedmiu kart złożony, z dokładnym tychże objaśnieniem... (The small pocket atlas with seven cards made up, with a clear explanation of them...) appeared in Wroclaw edited by the publishing house of Wilhelm Bogumił Korn. B. Olszewicz (1998) believed, that this atlas was issued several times; according to him, the second edition was published before 1806, the third one was released in 1806, another one - in the years 1818-1831; whereas J. Piasecka (1991) treats these atlases as the successive editions of three different positions. With the light of the research undertaken, it is essential, that all these atlases were compiled on the initiative of the same publishing house, which specialized, among others, in geographical and cartographical publications and used its own maps in various configurations. The Korns Publishing House had, in fact, its Polish division, which offered in the period of the years 1800-1837 more than 1,000 positions (B. Borowska-Żmigrodzka 1991), however, it was barraged with the accusations of the lack of due care for the language (E. Boczar 2015). According to K. Estreicher, the Korns Publishing House had released till the year 1830 more works in the Polish language than any other Polish publisher in the nineteenth century (E. Gondek 1989). One should agree with the statement of E. Herden (2005, p. 25), that the Korns' publications can be "a measure of social acceptance of diversity in a multicultural society" and a proof of the actual social needs, as the Korns would rather not invest in non-profit editions. In this context, it is difficult to recognize these atlases as the Polish adaptations; we rather tend to consider them as the Polish-language versions of the atlases compiled by this publisher.

The individual issues of atlases differed mainly in the number of maps (there were 7 maps in the first version, the last one counted up to 25) and in the titles, which, together with the changes in the number of maps, had been modified. In the fourth edition from 1818 entitled as Atlas nowy geografii dla użytku szkolnego (The new atlas of geography for school use) containing 23 maps, there were the geographical names changed from French into German. In the version for the Polish readers there were the explaining texts added and the Polish-language titles of maps, albeit inconsistently, introduced. As the result of this - writes J. Piasecka (1991) - the maps of former Polish territories looked "drastically", whereas the names of the rivers and major cities remained German regardless of the region. The table 20 contains the map of the Polish Kingdom and a large part of the Prussian state. The edition of the atlas from the year 1825 is entitled as Atlas nowy geografii dla użytku szkolnego z 24 kart złożony, zwłaszcza do Geografii Steina stosujący się (The new geographical atlas for school use from 24 cards composed, especially for the Geography of Stein applying to). On the other hand, the fifth edition was advertised in Geografia powszechna według zbioru C.B. Steina (The general geography according to the collection of C. B. Stein) (Wrocław 1831), Professor of gymnasium in Berlin, as Nowy Atlas geografii (...) z oznaczeniem teraźniejszych granic... (The New Atlas of geography $(. .$.$) with the designation of pre-$ sent borders...).

Another publication is Atlas geograficzny dla użytku szkolnego i prywatnego złożony z 24 kart przez Juliana Loewenberga (The geographical atlas consisting of 24 cards for school and private use compiled by Julian Loewenberg), edited by F. Silber in Berlin in 1843. According to B. Olszewicz (1998), this publication is a Polish adaptation of the German atlas, which filled the place on the publishing market after the atlases of Korn. The second edition took place in the year 1850 (J. Piasecka 1991). On all the maps there were the geographical names in Polish used. The atlas is constituted by 24 maps, one of which (no 21) presents "The Polish Kingdom" (fig. 2). Our assessment, as in the case of atlases of the Korns Publishing House, situates this item within the group of the Polish-language versions of foreign atlases.

The most known position from the time of partitions is: B.[Błażeja] Kozenna atlas geograficzny dla szkół średnich i wydziałowych spolszczył prof. dr. E.[Eugeniusz] Janota poprawit i uzupełnił Bronisław Gustawicz (...) w Wiedniu nakładem Edwarda Hölzla1 (The B. Kozenn

\footnotetext{
1 So was entitled the atlas from a new, second version of its adaptation, edited in the years 1879-1891. The first Polish version of the Kozenn atlas translated by S.E. Stroeger appeared in 1861 and was entitled Atlas geograficzny dla szkół gimnazjalnych, realnych i handlowych państwa austriackiego (The geographical atlas for high, real and commercial schools of the Austrian state) (J. Piasecka 1991).
} 
geographical atlas for the secondary and departmental schools, polonized by Prof. dr. E. [Eugene] Janota, improved and expanded by Bronislaw Gustawicz (...), in Vienna edited by the Edward Hölzl Publishing House). From the Preface to the atlas, written by B. Gustawicz, follows, that the main author of the polonized version was since the year $1870 \mathrm{E}$. Janota. B. Gustawicz undertook his own improvement at the request of the publisher only after the death of E. Janota. The atlas repeatedly left the printing press, but it can be assumed, that actually three basic issues appeared, successively updated, corrected and supplemented. Although the Polish version - like the original first edition of the atlas from 1853 (Geographische... 1861) - met with the fierce criticism (M. Mścisz 1925), indicating "the careless, full of German words" translation (J. Staszewski 1966 , p. 370), however its high popularity proves its issuing until 1926, already in the independent Poland (J. Piasecka 1991).

The analysis conducted by M. Zych (2006) shows, that the next editions of the atlas contain a large number of the Polish names (exonyms) relating to the areas outside the Polish territory. Quite surprising is the fact, that the number of exonyms in the atlas compiled by B. Kozenn, prepared for the Polish students by Seweryn E. Stoeger, a teacher from Nowy Sącz, improved by dr. E. Janota, a philologist of German, and later - by B. Gustawicz, a high school teacher from Krakow and Żywiec, is clearly higher than in the school atlases issued in the interwar period by E. Romer (M. Zych 2006).

From the same Viennese publishing house, the E. Hölzl Publishing House, Atlas geograficzny dla galicyjskich szkół ludowych (The geographical atlas for the Galician folk schools) by V.[Vincent] Haardt came (the first edition 1883) (K. Estreicher 1907). The Polish element in this atlas are the geographical names by B. Gustawicz, who had already cooperated at that time with the publisher on the occasion of adaptation of the B. Kozenn Atlas. The history of the functioning of this position on the Polish publishing market had its continuation in the period of Polish independence, because the last fifth edition of the atlas was published in the year 1930. B. Gustawicz was also the author of an atlas, which obtained the title Atlas geograficzny dla szkół ludowych i wydziałowych (The geographical atlas for the folk and departmen- tal schools). The atlas released by the author himself in Krakow in 1910 was the compilation of maps from the Kozenn atlases (edition 1898) and the Haardt atlases (1883), supplemented with five maps compiled by the author (E. Szynkiewicz 2004).

Among the general geographical atlases from that period should be recalled Wielki Atlas Geograficzny (The Great Geographical Atlas), often called the atlas of Wacław Nałkowski and Andrzej Świętochowski. There is no doubt with this atlas, that it is a complex adaptation. The basis for the compilation of this Polish adaptation was the third edition of Grosser Hand-Atlas by Heinrich Kiepert from the years 1892-1900. The Polish edition of the atlas was completed by two tables with eight climate maps of the world, the ethnographic maps of Europe and the world and maps of Galicia and Polish Kingdom. This edition was published in booklets, first released by the efforts of the Editors of „Wędrowiec" ("Wanderer"), then - by the Bookshop of Saturnin Sikorski. The fascicles, issued for over 10 years (1895-1906), did not maintain an order of the tables in its original state, an order in the number of 53 is found in the framed copies of the atlas, but the table of contents placed at the beginning of the publication does not take into account the page numbering. The order of arrangement of the tables draws the attention: this order - according to J. Staszewski (1966) - was changed by the publishers in accordance with the concept of W. Nałkowski. The atlas is opened by the hemispheres (tables no. 3 and 6), a map of the world in Mercator projection, one can find further two tables with maps of the climate elements and explanatory text, "The ethnographic map of the Earth" (no 57 and 58), then - the only table without any maps "The comparative summary" graphically illustrating the size of the countries (i.e., area and population), as well as the river basins and peak heights. The regional part is opened by "Australia and Polynesia", the maps of South and North Americas (in that order); then placed the maps of Asia and relatively detailed maps of the regions of Europe in twenty tables. At the end of the maps of the European countries one can find two maps of the Polish lands. The author of the map of Galicia at the scale 1:1,055,072 was a geographer from Lvov and valued cartographer Stanisław Majerski (fig. 3). He was 
famous, because of his compilation of three hypsometrical maps, but for the needs of the atlas discussed, he compiled a map without a terrain relief, marking the river network, the rich settlements and communication network. the volume of an atlas is a number of the names on an index. In the discussing adaptation almost every map (with the exception of the first tables) has its own separate index. Summing up roughly the number of geographical names, we get

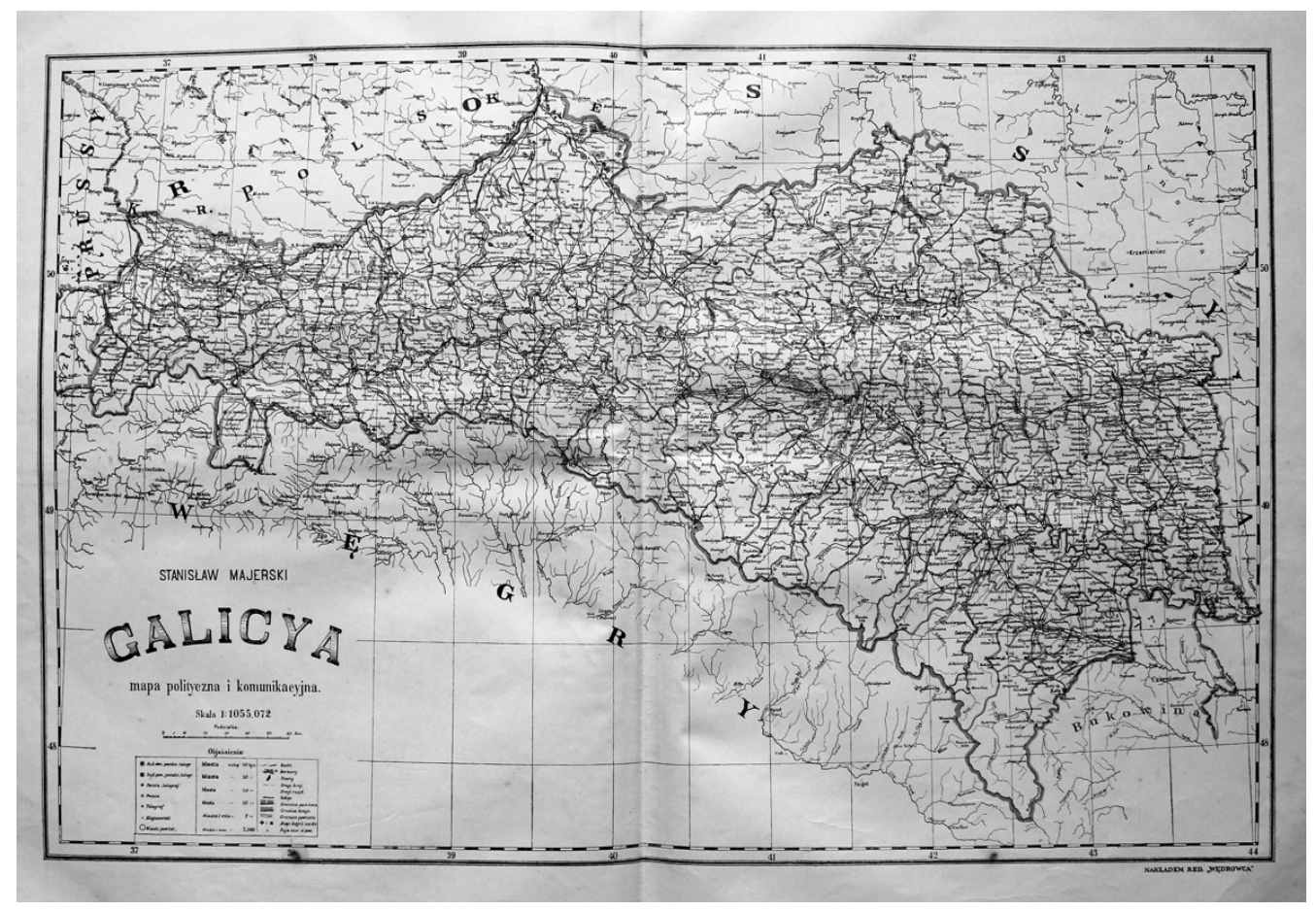

Fig. 3. The map of Galicia from Wielki Atlas Geograficzny (The Great Geographical Atlas) by W. Nałkowski and A. Świętochowski (source: http://www.atlassen.info/atlassen/pools/watge01/picsxl/watge1904k048.jpg)

"The map of the province of Polish Kingdom" at the scale $1: 1,000,000$ due to its format is the only foldable map and it differs in its graphical form from the other maps. Four regional maps of Russia closed the atlas.

The geographical names were translated into Polish from the finished clichés taken from the Berlin atlas (J. Staszewski 1966). The subscribers received the fascicles containing generally two map tables and indexes of the geographical names appearing on those maps. Apart from the position of the village in the fields specified by the geographical grid, entering the number of urban residents was also a rule. The extensive economic and political descriptions followed the index. Usually, a measure of a number of about 100 thousand, but it should be noted, that in this way the same name is counted several times, if it is situated on several maps. Thus, the estimated number, which is given, should be reduced by $20-30 \%$. For the comparison, Atlas Świata (The World Atlas) compiled by the Topographic Service of the Polish Armed Forces in 1962-1968 includes about 140,000 names. It is necessary to mention, that the local names, the pronunciation of which was explained in the legend, were used in a few sheets (B. Kosiorowska 1997). The atlases stored in libraries have the indexes framed together with the comments either before each map or at the end of the atlas. The authors, customizing the atlas for the Polish readers, 
have put quite a lot of work not only in Polonize the geographical names, but also into the compilation of the mentioned texts, hence the atlas is a complex adaptation.

\subsection{The interwar period}

The most known publication from the period of partitions of Poland is the B. Kozenn Atlas. Probably, the different causes, as numerous reprints and decades-long presence of this atlas on the Polish publishing market, are due to this fact. M. Polaczkówna (1924), noting a number of shortcomings of the atlas, was aware, that for some time it will have to meet the needs of the Polish users; she wrote: "...we are waiting patiently, because it has been heard, that the relevant Polish atlas is already reached an advanced stage in the preparation" (p. 371). The last issues of the Kozenn Atlas took place in 1923, 1924 and 1926 (J. Piasecka 1991), so just before and just after the release of the first E. Romer "patiently expected" fascicles of Powszechny atlas geograficzny (The general geographical atlas) (1925-1927).

The Polish editions of the B. Kozenn Atlas issued after he Treaty of Versailles were prepared without any substantial supervision of the authors. E. Maliszewski (1924), writing a note recording the edition from the year 1923 in "The Bibliographic Review", entitled it as "A harmful atlas". He stressed, that the concept of the atlas was completely not useful for the new school, giving as an example the fourth chapter "The countries at the Danube River and Poland", in which only one table from eight ones devoted to the former Austrian-Hungarian monarchy contained the territory of Poland; then he pointed out and discussed the errors, which were the evidences of the lack of cartographical reliability during the preparation of this issue, absolutely disqualifying it as a publication dedicated to the Polish school.

A similar fate befell the second atlas coming from the E. Hölzl Publishing House. A Polish version of the Haardt Atlas was released for the last time in 1930. It was printed in Krakow from the Vienna clichés, without any correction and supervision "....and, as an effect, because those clichés had already not been revised by anyone responsible in Poland, it swarmed directly from nonsense, shortcomings and mistakes"
(J. Wąsowicz 1933, p. 100). There is no certainty, but probably the Viennese publisher, seeing no longer the economic justification for issuing the Polish version of his own atlas, got rid of the unusable plates for the publisher from Krakow, who was attempting to update it in a bumbling way, e.g., by entering the wrong lines of boundaries. J. Wąsowicz in his analysis published in "The Polish Cartographical Review" (1933) was very critical to the fifth edition of the atlas and described it - as E. Maliszewski ones wrote about the B. Kozenn Atlas - as a harmful school aid.

The next publication of Atlas Geograficzny (The Geographical Atlas) by Stanisław Korbel was issued in 1938 in Katowice by the Cartographical Publishing Company "Globus". This atlas is characterized by the Polish geographical names and a great number of maps concerning Poland. S. Leszczycki (1983) considered it to be an adaptation of the Kozenn Atlas. However, in our opinion, it is not an adaptation, but the result of inspiration and imitation of foreign cartographical school. There is no doubt, that the Austrian publications were the models to follow for the author.

\subsection{The period after the Second World War (until 1989)}

Five years after the end of the World War II Jerzy Kondracki had adapted the Czech Kapesni atlas by Karel Kuchař from the year 1947 . The adaptation in a kind of complex one appeared as Atlas kieszonkowy (The pocket atlas) edited by K. Kuchař and J. Kondracki twice: in 1950 and 1951. As J. Kondracki mentioned, the adaptation of the atlas for the Polish readers "consisted of (...) the replacement of the Czech geographical names by the Polish ones (fig. 4), the maps of Czechoslovakia and surrounding area of Prague by the maps of Poland and Warsaw area and some changes in the order and content of some maps, as well as the photographic illustrations" (J. Kondracki 1993, p. 28). The map of the world was also newly edited. So, it was quite far advanced adaptation by the Polish editor. The atlas contains an index of about 10 thousand geographical names. At the end J. Kondracki wrote: "The liquidation of the private publishing companies in the early fifties put the end to the further resuming the atlas". 


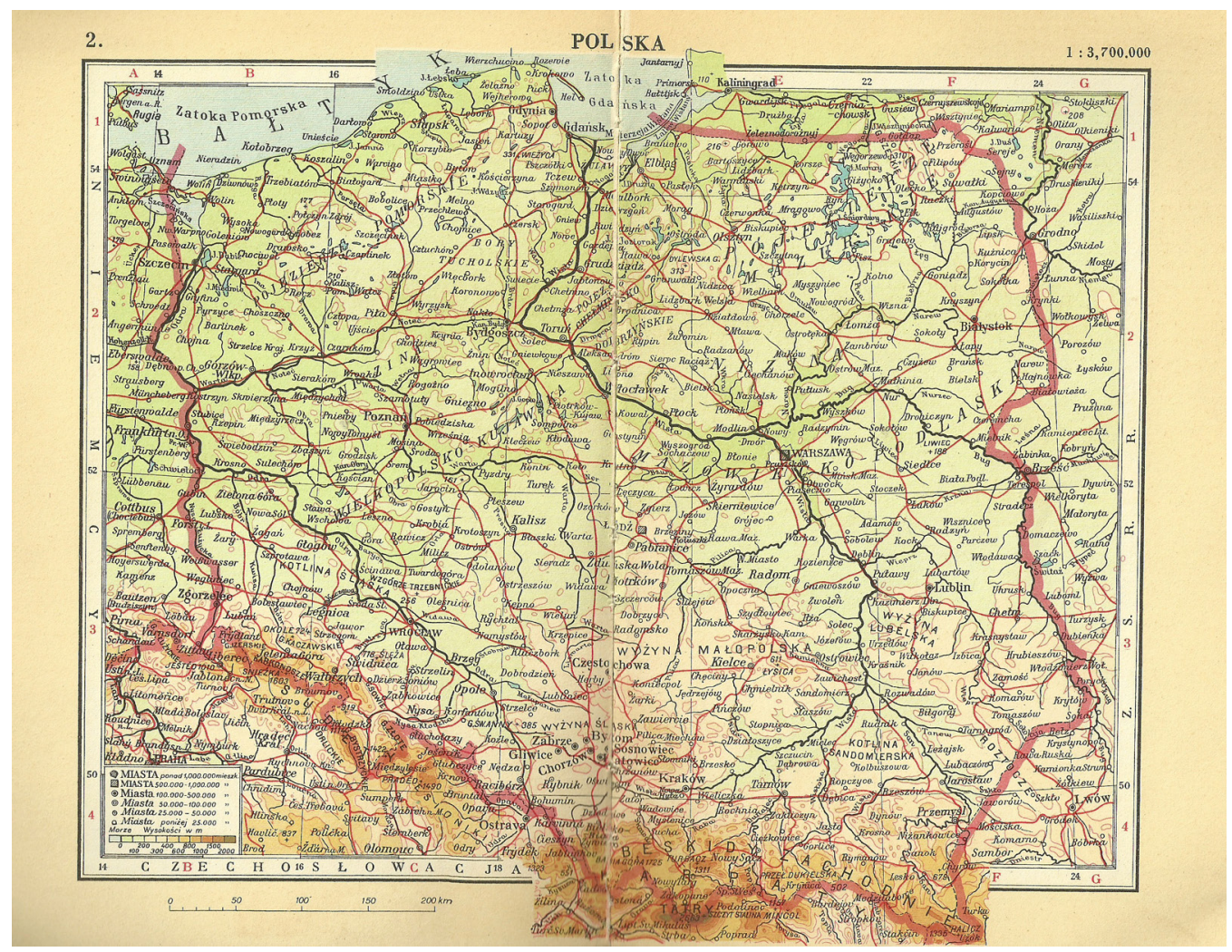

Fig. 4. The map of Poland from Atlas kieszonkowy (The pocket atlas) by K. Kuchař and J. Kondracki

The publisher of the atlas was the Publishing Bookstore Trzaska, Evert and Michalski, hence in the bibliographical records the publication also appears as: Trzaski, Everta i Michalskiego atlas kieszonkowy (The Trzaska, Evert and Michalski pocket atlas). Both issues were printed in Prague.

Another adaptation in the form of a pocket atlas was published twice by the State Cartographical Publishing House (PPWK) in 1969 (1970) and 1971. In the foreword to the atlas it was explained, that PPWK reached for the ready compilation of Haack Kleiner Weltatlas, despite having in the publishing offer its own, similar Atlas świata (Atlas of the word), under the influence of the book market demands and the lack of free processing capacities, because the activity of the company at that time was dominated by the needs of education (atlases, wall and cache maps). In favour of the preparation of German atlas, instead of updating its own, spoke much a larger number of geographical names - about 21 thousand, while the PPWK atlas contained about half of them less (L. Ratajski 1970). The maps included in the adaptation characterized by an excellent readability and pleasant colours, which "were not spoiled even by an introduction of the delicate terrain shading of the lands" (L. Ratajski 1970, p. 77). The atlas was printed in the former German Democratic Republic. According to L. Ratajski, the biggest drawback of the atlas was an incomplete adjustment to the needs of the Polish customers in the layer of naming. The atlas used the official names by adding only in a few cases the Polish names in the parentheses.

Another Polish complex adaptation, which was published before 1989, was Atlas geograficzny dla dzieci. Świat i człowiek (The geographical atlas for the children. The world and a man) edited in 1988 by the State Publishing House "The Common Knowledge" based on 
the Soviet publication Mir i čelovek. Geografičeskij atlas (The world and a man. The geographical atlas), published in Moscow in 1987 by the Head Office of Geodesy and Cartography of the USSR in Moscow. From the point of view of cartography, it was an insignificant position, but extremely popular and well-remembered by its users, both, the users of adaptation and original ${ }^{2}$. In the Polish version aside from the translations of explanatory texts and a supplement to the table called "The Conquest of Space" with the portrait of Polish cosmonaut M. Hermaszewski, the maps of the USSR were replaced by five Polish maps at the scale $1: 3,000,000$ - physical map, a map of plants, animals, nature protection and administrative maps (Nowości wydawnicze..., 1989) (New publications..., 1989).

\section{Conclusion}

Referring to the kinds of adaptations, that have been highlighted in the second issue of PCR (B. Konopska, J. Pasławski 2015), it is necessary to determine, that the main principles of the compilations of adaptations in earlier periods were quite alike.

The features of the complex adaptations were shown with the help of the atlases of D. Szybiński, W. Nałkowski and A. Świętochowski, K. Kuchař and J. Kondracki, as well as the publication Świat i człowiek (The world and a man). Using the reviews and overviews of those adaptations, written at the time, when they were issued, it should also be noted, that the biggest workshop problem of the cartographers in every period was the geographical naming, as in the case of adaptations after the year 1989.

The features of the basic adaptations were revealed by the atlases, which came from the publishing offices of W.B. Korn, F. Silber and E. Hölzl. In our opinion, they can be included to the adaptations, but we cannot call them the Polish adaptations; due to their origins we suggest to classify them as the Polish-language versions of foreign atlases. These atlases were compiled by the foreign publishers with their

\footnotetext{
2 http://www.lupuslibri.pl/2013/09/swiat-i-czowiek-atlas-geograficzny-dla.html [entry 20.12.2015]; http://backtotheussr. tumblr.com/post/13071447462/matrabbit-мир-и-человекman-the-world (access: 20.12.2015).
}

own materials, in order to expand an offer and to exploit the Polish-language market for the needs of Polish users, who, due to the politics, were within their countries. The genesis of the previous Polish foreign adaptations resulted from the adjustment of foreign publications for the Polish users and introducing to the Polish market by Polish publisher.

In the period analysed (until 1989) one can notice some specific trends connected with the political history of Poland and development of Polish cartographical activities. After the loss of independence a lot of Polish-language versions of atlases appeared, edited by the publishing houses of the partitioning powers. In the Prussian partition there were the Polish-language German atlases available, published in Wroclaw and Berlin, in the Austrian one - atlases were compiled and printed in Vienna, but in the Russian partition German and Austrian translations of the atlases were used. The compilations were the results of the decisions of publishers, who saw the economic sense in expanding their offers. For example, the E. Hölzl Geographical and Editorial Enterprises translated the atlases not only for the Polish-speaking citizens of the empire, but also for another small nations belonging to the monarchy of the Austrian-Hungarian Empire. E. Hölzl had seen the economic sense in meeting the needs of foreign citizens until the recovery of the independence of each country. Regarding the reconstructions of the countries partitioned, and, along with these reconstructions, the creation of cartographical publishing houses of these reconstructed countries, he discontinued with the investments into the updates of these publications.

Nevertheless, the external circumstances encouraged some Polish-language atlases to persist in the publishing circulation even after the independence. Polish cartographical publishing houses had been just organized and until they filled the market with their own publications, so long they filled it with foreign compilations. In the first decade of the existence of the Second Republic of Poland it was noted the further issues of the B. Kozenn and W. Haardt atlases. However, towards the changes, that had occurred in Poland after the independence, the usefulness of these atlases were already highly questionable, especially those intended 
for schools. In a free country - in the absence of danger - the reviewers of these atlases were more explicit in formulating the critical assessments (M. Polaczkówna, E. Maliszewski, J. Wąsowicz).

The adaptation in the Second Republic of Poland (1918-1939) was not a popular form. The compilations of own Polish atlases were completely understandable phenomena at that time. The cartographical activities had been taken by three centres - in Krakow, Warsaw and Lvov. Just as in the interwar period, after the World War II, the general policy of the state in the communist period was not conducive to the marketing of foreign publications, understood

\section{References}

Augustowska K., 1960, Atlas dziecinny Szybińskiego. Kartka z dziejów naszej geografii szkolnej. „Geografia w Szkole" R. 13, nr 6, pp. 278-290.

Boczar E., 2015, Wydawcy polskich książek dla dzieci i młodzieży w zaborze pruskim w XIX wieku. "Acta Universitatis Lodziensis. Folia Librorum" T. 1 (20), pp. 9-32.

Borowska-Żmigrodzka B., 1991, Wprowadzanie joty w XIX-wiecznych drukach wrocławskiej oficyny Kornów. „Prace Językoznawcze” Nr 19, Studia Polonistyczne, eds A. Kowalska, A. Wilkoń, pp. 23-29.

Geographische Literatur. „Mittheilungen aus Justus Perthes Geographischer Anstalt...", Gotha 1861, pp. 406-408.

Gondek E., 1989, Zapotrzebowanie na książkę literacką w pierwszej połowie XIX wieku w świetle działalności śląskich oficyn wydawniczych. „Prace Komisji Historycznoliterackiej” nr 9, Śląskie Miscellanea, eds J. Malicki, K. Heska-Kwaśniewicz, pp. 71-89.

Herden E., 2005, Książki do nauki języka polskiego w repertuarze wydawców śląskich okresu oświecenia (1750-1820). In: Historia książki na terenach pogranicza i jej rola w kształtowaniu społeczeństw wielokulturowych, ed. K. Raczyńska. Zielona Góra: Pro Libris, pp. 19-30.

Kondracki J., 1993, Pierwszy powojenny atlas świata w języku polskim. „Polski Przegl. Kartogr.” T. 25, nr 1, pp. 27-28.

Konopska B., Pasławski J., 2015, Polish adaptation of foreign geographical atlases for general use at the turn of the 20th and 21st centuries. "Polish Cartographical Review" Vol. 47, no. 2, pp. 77-90, DOI: 10.1515/pcr-2015-0009, November 2015.

Kosiorowska B., 1997, Wacław Nałkowski - znany geograf, zapomniany kartograf. M.A. thesis - Cartographic Department, University of Wrocław. as those from the outside the Eastern bloc. At that time the state decided centrally what editorial positions could hit the market and who would release them; the compilations of adaptations of the works published in the so-called friendly countries were tolerated (Atlas kieszonkowy - Czechoslovakia, Świat i człowiek - USSR).

In the light of the above mentioned facts, the results of this study confirmed the thesis, which was put at the beginning, that the activities of authors and publishers in the scope of adaptations of the atlases depend mainly on the external circumstances, primarily on the political and socioeconomic ones.

Kowalczyk M.E., 2014, „W powszechny zwyczaj to weszło, zaczynać młodzi płci obojej naukę od geografii", czyli o kulturotwórczej roli podręczników geograficznych w Polsce XVIII wieku, „Kwartalnik Historii Kultury Materialnej” R. 62, nr 4, pp. 567-578.

Leszczycki S., 1983, Geografia w Krakowie w okresie międzywojennym. „Czasopismo Geograficzne” T. 54, z. 3, pp. 289-308.

Lewicki J., 1910, Geografia czasów Komisji Edukacji Narodowej. Lwów - Warszawa.

Łodyński M., 1960, Organizacja bibliotek szkolnych Księstwa Warszawskiego i Królestwa Polskiego w latach 1807-1831. „Przegląd Biblioteczny” R. 28, z. 1, pp. 1-31.

Maliszewski E., 1924, Szkodliwy atlas. „Przegląd Bibliograficzny” R. 10, nr 15, pp. 241-242.

Mścisz A., 1925,(rev.) Kozenn. Atlas geograficzny. „Czas. Geogr.” T. 3, z. 3/4, pp. 289-290

Nowości wydawnicze. Mapy $i$ atlasy, 1989, „Polski Przegl. Kartogr." T. 21, nr 1, pp. 36-37.

Olszewicz B., 1998, Kartografia polska XIX wieku (Przegląd chronologiczno-bibliograficzny), ed. W Wernerowa, T. 1, Warszawa.

Olszewicz, B., 2003, Kartografia polska XVIII wieku (Przegląd chronologiczno-bibliograficzny), Warszawa.

Piasecka J.,1991, Polskie przekłady szkolnych map i atlasów geograficznych. „Polski Przegl. Kartogr.” T. 23, nr 4, pp. 121-129.

Polaczkówna M., 1924, Polskie mapy szkolne $i$ atlasy. „Czasopismo Geograficzne” T. 2, z. 3-4, pp. 370-375.

Polaczkówna M. 1925, Plany nauczania geografii wedle Wielkiej Komisji Edukacyjnej - jej drogowskazy dla współczesnych. „Pokłosie Geograficzne”, Lwów 1925, pp. 179-206.

Ratajski L., 1970, rev.: Kieszonkowy atlas świata. „Polski Przegl. Kartogr.” T. 2, nr 2, pp. 76-77. 
Spallek W., 2014, Kształtowanie się koncepcji map ogólnogeograficznych w świetle polskich atlasów szkolnych wydanych do 1939 roku. In: „Z Dziejów Kartografii" T. 18, Dawne mapy jako źródła w badaniach geograficznych i historycznych, eds B. Konopska, J. Ostrowski, Warszawa.

Staszewski J., 1966, Historia nauki o Ziemi w zarysie. Warszawa: PWN.

Szaniawska L., 1987, Analiza wybranych małoskalowych map ziem polskich (XVI-XVIII w.). „Studia i Materiały z Historii Kartografii" T. 7. Warszawa: Biblioteka Narodowa.

Szybiński D.G., 1772, Atlas dziecinny, czyli nowy sposób do nauczania dzieci geografii, krotki, łatwy.... Warszawa: M. Groll.
Szynkiewicz E., 2004, Szkolnictwo i kartografia szkolna w Galicji. In: „Z Dziejów Kartografii” T. 13, Kartografia Galicji 1772-1918, ed. J. Ostrowski, Warszawa, pp. 215-242.

Wąsowicz J., 1933, rev.: W. Haardta Atlas geograficzny. „Polski Przegl. Kartogr.” T. 11, nr 43, p. 100.

Zych M., 2006, Polskie egzonimy w atlasach szkolnych w latach 1901-1989. „Polski Przegl. Kartogr.” T. 38, nr 1, pp. 24-45.

atlassen.info/atlassen/pools/watge01/watge $01 . \mathrm{html}$ (access: 15.07.2015).

lupuslibri.pl/2013/09/swiat-i-czowiek-atlas-geograficzny-dla.html (access: 20.12.2015).

backtotheussr.tumblr.com/post/13071447462/ matrabbit-мир-и-человек-man-the-world (access: 20.12.2015). 